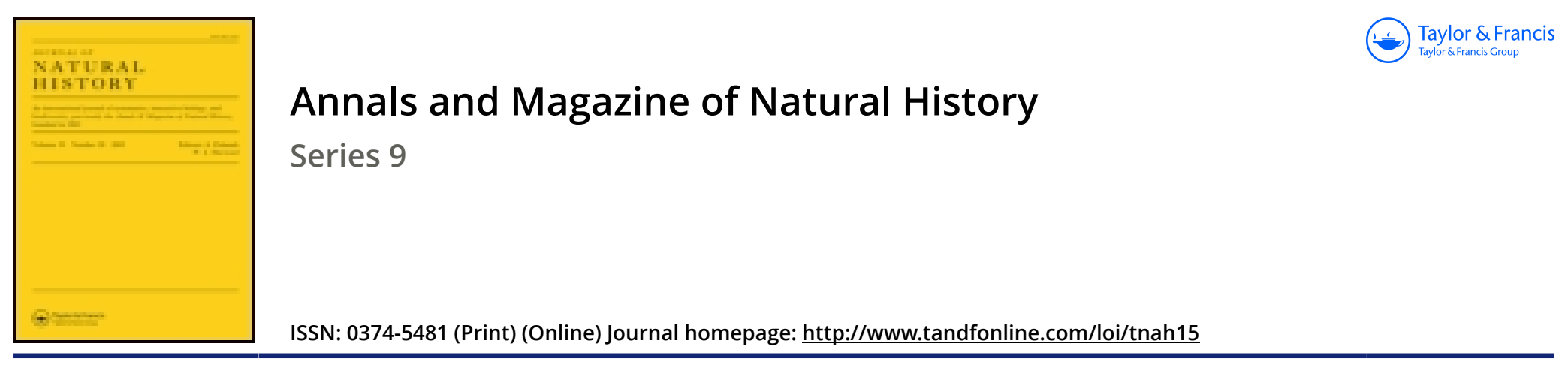

\title{
XX.-New Australian Hymenoptera of the family Evaniidæ in the British Museum
}

\section{Rowland E. Turner F.Z.S. F.E.S.}

To cite this article: Rowland E. Turner F.Z.S. F.E.S. (1918) XX.-New Australian Hymenoptera of the family Evaniidæ in the British Museum , Annals and Magazine of Natural History, 2:9, 197-203, DOI: $10.1080 / 00222931808562365$

To link to this article: http://dx.doi.org/10.1080/00222931808562365

$$
\text { Published online: } 04 \text { Sep } 2009 .
$$

\section{Submit your article to this journal $\square$}

Џ Article views: 2 


\section{XX.-New Australian Hymenoptera of the Family Evaniidie in the British Museum. By Rowland L. Tunner, F.Z.S., F.E S.}

Evania sericans, Westw.

Evania sericans, Westw. Trins. Ent. Soc. London, (2) i. p. 215 (1851).

Kieffer places this species in the section of the genus without spines on the hind iibia, probably because Westwood makes no mention of such spines; but the spines are really well developed. Though widely sprear, the species seems to be uncommon.

Hab. Kuranda, Queensland (Turner), May 1913; Mackay, Queensland (Turner), March 189: ; Victoria (French); Yallingup, S.W. Australia (Turner), December; Kalamunda, S.W. Australia (Tumer), February 1914.

\section{Evania perfida, Westw.}

Evania perfida, Westw. Trans. Ent. Soc. London, (2) i. p. $216(1851)$. o .

This is also erroneously placed by Kieffer in the section without spines on the hind tibiæ. Westwood states that his type came from Tasmania. but the specimen marlied by him as perfida in the British Nuseum, which is undoubtedly the type, is trom S.W. Australia. I have taken it at Yallingup, and it also occurs at Adelaide.

\section{Pseudoficenus cylindricus, sp. n.}

Q. Nigra, gracillima; mandibulis, apice excepto, testrceis; tibiis macula basali, tarsisque anticis intermedisque pullide fiktobrumneis; terebra, valvulisque apice pallide flavis; alis hyalinis, iridescentibus, venis fuscis, stigmate testaceo.

Long. $9 \mathrm{~mm}$.; terebræ long. $1.5 \mathrm{~mm}$.

q. Second joint of the flagellum short, distinetly slurter than the first, the third half as long again as the sccond, the flagellum clothed with very short black hairs. llead very long and narrow, about four times as long as lrcad; the eyes elongate-ovate, separated from the hind maryin of the head by a distance about half as great as their leugth; the anterior ocellus situated well behind a line joining the summit of the eyes; the hind margin of the head not carinate. Neek as long as the distance between the tegulas and the anterior angle of the mesonotum. Thorax iong and narrow, subcylindrical, the mesonotum roumded anteriorly; Ann. \& Mag. N. Mist. Ser. 9. Fol. ii. 
parapsidal furrows very shallow and narrow, almost obsolete; scutum much longer than the scutellum; median segment with a longitudinal groove. Head and thorax opaque, withont sculpture, the face below the antenna finely punctured. Petiole 2-jointer, the basal portion formed by the first sternite very slender throughout, the apical portion fully half as long again as the basal, gradually widened towards the apex; second segment about equal in length to the basal portion of the petiole; tergites $2-5$ much longer than broad. Terebra scarcely longer than the basal portion of the petiole, slender. Hind tibiæ strongly swollen; hind metatarsus nearly equal in length to the four apical tarsal joints; tarsal ungues small. Wings small and short, not reaching beyond the apex of the second tergite.

The male has the second and first joints of the flagellum equal, the third as long as the first and second combined.

Hab. Kalamunda, S.W. Australia (Turner), February 1914. Three females and one male. Easily distinguished by the long narrow head and thorax and short terebra. Not nearly related to the New Zealand group typical of the genus, but nearer to American species such as angustatus, Kieff. 'The species included in Pseudofoenus by Kieffer seem to fall into two crroups, one, including the type of the genus, appronching Hyptiogaster, the other mnch nearer to Fonus. The first group is confined to New Zealand.

\section{Psendofornus fluvialis, sp. n.}

o. Nigra; mandibnlis tegulisque testaceis: tihiis macula basali, tibiis anticis apice, tarsis anticis, enetatarsisque intermediis posticisque albidis ; terebra valvulisçue nir ris, apice albidis ; alis hralinis, iridescentibus, venis nigris, stigmate brunneo; terebra abdımine paullo breviore.

Long. $11 \mathrm{~mm}$; t terebre long. $6 \mathrm{~mm}$.

q. First joint of the flagellum very little longer than the sccond, the two combined distinctly shorter than the third. Head long and narrow; cheeks very short. almost obsolete; hear feehly margined posteriorly, narrowed behind the eyes, which are separated from the hind margin of the head by a distance equal to about one-third of their own length. Anterior ocellus situated just in front of the line joining the summits of the eyes. Head and thorax opaque, without sculpture, clypens finely and closely punctured. Neck as long as the distance betwcen the tegula and the front of the mesonotum; parapsidal furrows narrow, but distinct, finely crenulate; mesonotum rounded anteriorly, scutum as 
long as the scutellum. Median segment very delicatcly rugulose, with a low longitudinal carina, hind coxe fincly graunlate. Abdomen long and slender, the first tergite twice as long as the second. Hind metatarsus as long as the four apical tarsal joints; tarsal ungues small.

Hab. Perth, W. Australia (Turner), February. Two females taken on blossom of Eucalyptus calophylla in King's Park.

This is much nearer to the Mexican species, $P$. angustatus, Kieff., than to P. cylindricus, but differs in the sculpture of the thorax, the shape of the head, and other details. Kieffer gives two species of Pseudofonus as Australian, but $P$. unguiculatus, Westw., is from New Zealand, and darwinii, Westw., belongs to Hyptiogaster.

\section{Pseudofenus isthmalis, sp. $\mathrm{n}$.}

‥ Nigra; mandibulis fuscis; palpis pallidis; tibiis anticis intermediisque supra, metatarsis anticis intermediisque, tarsis anticis articulo secundo, tarsis posticis, basi extrema articuloque apicali nigris, val rulisque terebre tertio apicali albidis; pleuris sternoque live illic nigro suifusis, coxis, trochanteribus, femoribasque anticis ferrugineis; tibiis posticis basi intra albo-maculatis; nhis hyalinis, leviter suffusis, iridescentibus, stigmate veuisque nigris ; terehra corpore vix breviore.

Long. $10 \mathrm{~mm}$; t tercbre long. $9 \mathrm{~mm}$.

q. First joint of the fagellum as broad as long, haif as long as the second, third fully as long as the first and sccond combined. Head long ant narrow, feebly margined and rather strongly emarginate on the hind margin; front convex, subcarinate longitudinally in the middle; cheeks almost obsolete. Anterior ocellus almost on a lerel with the summit of the eyes, which are separated from the hind margin of the head by a distance equal to slightly more than one-third of their ow length. Ieal oparie, finely coriaceons. Neck nearly as long as the distance between the tegula and the front of the mesonotum; thorax opaque, very delicately rugulose, mesonotum with the anterior margin straight, only rounded at the angles, with two short impressed longitudinal lines from near the middle of the anterior margin; parapsidal furrows distinct, crenulated; scutum longer than the scutellum, prescutum much longer than the scutum. Median segment witl a distinct longitudinal carina, transversely rugulose. First abdominal segment twice as long as the secoud. Hind metatarsus as long is the funr apical tarsal joints: tarsal unijos small. 
Hab. Eaglehawk Neck, S.E. Tasmania (Turner), February 1913. One female.

Differs from fluvialis in the proportion of the antennal joints, the shape of the head, the sculirure of the thorax and median segment, the length of the terebra, in colour, and other details.

\section{Fienus autumnalis, sp. n.}

9. Nigra; mandibulis apice excepto, tegulis, pedibusque anticis intermediisquo ferrugineis; tibiis anticis intermediisque supra, tibiis posticis macula basali, tarsis anticis, tarsis intermediis articulis tribus basalibus, tarsisque posticis, basi apiceque excoptis, albis ; terebra, petiolo multo breviore, testacea ; valvulis apice albidis, incrassatis; alis hyalinis, venis fuseis; stigmate pallido, fusco-marginato.

Long. $14 \mathrm{~mm}$; t terebræ long. $2.5 \mathrm{~mm}$.

q. Head opaque, somewhat elongate, slightly swollen behind the eyes, the hind margin distinctly carinate. Eyes separated from the hind margin of the head by a distance equal to about one-third of their own length; posterior ocelli level with the summit of the eyes, twice as far from each other as from the eyes; cheeks very short, not half as long as the first joint of the flagellum; a longitudinal carina betwcen the antennæ. Second joint of the flagellum more than half as long again as the first, the third joint distinctly longer than the first and second combined. Neck short; pronotum with a very short and small spine at each angle; mesonotum opaque, coriaceous, with two very short longitudinal impressed lines from the anterior margin; scutellum with well-rlefined marginal carinæ; median segment rather coarsely rugose-reticulate, with a rather indistinct median carina ; hind coxa coriaceous. Hind metatarsus no longer than the four apical tarsal joints combined, the basal third black, the apical half of the fifth tarsal joint also black. Terebra scarcely half as long as the petiole.

Hab. Kalamunda, S.W. Australia (Turner), March 1914. Four females.

Closely allied to valvularis, Schlett., but differs in the lesser development of the angles of the pronotum, in the sculpture of the median segment, and in the shorter cheeks. $F$. fuscimanus, Kieff., has the terebra distinctly longer, the cheeks longer, and the sculpture of the thorax rather stronger ; and $F$. valens, Kieff., is a much larger insect, more robust, with the sculpture of the median segment tending to transverse striæ and the coxæ black. 
Fonus exilis, sp. $\mathbf{n}$.

․ Nigra, minuta; mandibulis tegulisque testaceis; tibiis anticis intermediisque, tibiis posticis basi, tarsis anticis intermediisque, tarsisque posticis subtus pallide brunneis; terebra, petiolo multo breviore, testacen; valvulis apice albidis; alis byalinis, iridescentibus, venis fuscis, stigmate fusco-ferrugineo.

Long. $7 \mathrm{~mm}$; t terebræ long. $1.5 \mathrm{~mm}$.

ㅇ. Head elongate, opaque, the hind margin very feebly carinate. Eyes separated from the hind margin of the head by a distance equal to half their own length; anterior ocellus situated a little behind a line joining the summit of the eyes; cheeks very short, not as long as the first joint of the flagellum; a low carina running from between the antennæe nearly halfway to the anterior ocellus. First joint of the flagellum scarcely longer than broad, second scarcely half as long again as the first, third distinctly longer than the first and second combined. Neck rather short, angles of the pronotum unarmed; mesonotum opaque, very finely coriaceous, with two short, obscure, longitudinal raised lines from the anterior margin, the curved line separating the prescutum and scutum very shallow and not crenulate. Scutellum without marginal carinæ; median segment irregularly transversely rugulose; hind coxæ very finely coriaceous. 'l'erebra more than half as long as the petiole; hind metatarsus as long as the four apical tarsal joints combined.

Hab. Mt. Wellington, Tasmania, $2200 \mathrm{ft}$. (Turner), January 1913. One female.

This is not nearly allied to the group of valvularis, Schlett., having the head slightly narrowed behind the eyes, the scutellum without carinæ, and the groove between the scutum and præscutum narrow and not crenulate.

\section{Fonus steindachneri, Schlett.}

Gasteruption steindachneri, Schlett. Verh. zool.-bot. Ges. Wien, xxxv. p. 300 (1885). 우.

Hab. Mt. Wellington, Tasmania, $2200 \mathrm{ft}$. (Turner). March.

F. leptotrachelus, Kieff., is very near this, but cannot be the male of this species, having the head much more strongly narrowed behind the eyes.

Fonus macrocephalus, sp. n.

o. Maxima, nigra; tibjis anticis intermediisque eupra, tarsis 
anticis intermediisque apice infuscatis, tarsisque posticis, metatarso tertio hasali articuloque quinto exceptis, albidis; terebra, corpore sesqui longiore, testacea, ralvulis apice extremo albidis; alis hyalinis.

Long. $30 \mathrm{~mm}$; terebra long. $15 \mathrm{~mm}$.

+ . Head opaque, finely coriaceous, massive, slightly swollen behind the eyes, the hind margin rather feebly carinated. Eyes separated from the hind margin of the licad by a distance equal to fully half their own length; posterior ocelli in a line with the summit of the eyes, fully half as far again from each other as from the eyes. Chetks as long as the first joint of the flagellum; a longitudinal carina between the antenuae. Second joint of the flagellum twice as long as the first, third nearly half as long again as the first and second combined. Neck very short; angles of the pronotum unamed. Thorax opaque, coriaceous, the sicles of the prosentiom with fine transverse strix; prosentum nearly twice as long as the scutum, with two short sligitly raiced lines converging from the anterior margin; the curred line dividing the sentum and proscutum broad and cremlated. Mredian segment irregularly transversely rugosestriate, with an indistinct median carina; hind coxæ shining, punctured at the base, finely transversely striated at the apcx; hind metatarsus about equal in length to the four apical tarsal joints; the fifth joint long, about equal to the second. Pleure fincly ruyose; mesosternum coarsely transversely striated, the sides of the median segment also coarsely striated.

Hab. Victoria (ex coll. Tumer, received through $C$. Fivench).

This is the largest species of the genns known to me. The head and thorax, especially on the sides, are clothed with very short white pubescence, as in $F$. breviscutum, Kieff. The radius is bent into a sharp angle at abont twothirds from its base, as in all the group of breviscutum.

\section{Fonnus calothecus, Kieff.}

(rustemption calothecus, Kieff. Ann. Soc. Ent. France, lxxx. p. 198 (1)11). 9 .

Specimens of this species from Yallingup, S.W. Australia, are larger than the type, measuring np to $20 \mathrm{~mm}$, with the terebra $60 \mathrm{~mm}$., but do not seem to differ appreciably in colour or structure. The type is from Queensland; the cotype has been labelled Mexico, evidently by mistake. 


\section{Frenus bicarinatus, sp. n.}

․ Nigra; mandibulis basi, pedibusqu tho anticis fusco-fermgineis; tibiis anticis intermediisque upra, tarsis anticis infermedisque apice infuscatis, tarsisque posticis, metatarsi tertio basali articuloque quinto exceptis, albidis ; terebra rufo-testacea abdomino paullo longiore, valvulis apice flavidulis et dilatatis.

Long. $22 \mathrm{~mm}$.; terebra long. $15 \mathrm{~mm}$.

q. Head not very strongly uarrowed behind the eyes, slightly swollen transversely behind the ocelli, opaque and coriaceons, the hind margin distinctly carinated. Eyes separated from the hind margin of the head by a distance equal to nearly half their own length; posterior ocelli in a line with the summit of the eyes, twice as far from each other as from the eyes. Cheeks half as long again as the first joint of the flagellum, a longitudinal carina between the antennis, the front depressed on each side above the base of the antennx; second joint of the flagellum twice as long as the first, third more than half as long again as the first and second combined. Neck rather short; angles of the pronotun almost unarmed. Mesonotum irregularly trausversely rugose-striate; with two longitudinal carinat from near the midhle of the anterior margin not reaching the middle of the pirescutum, the space between the carinæ transversely striated and deeply depressed. Pleurae rugose; median segment rather coarsely rugose, convex, with a longitudinal carina, the sides of the segment above the hind coxæe with a few coarse strix. Hind coxæ shining, rather indistinctly transersely striated. Ilind metatarsus as long as the four apical tarsal joints combined. Radius sharply bent upwards towaris the costa at about two-thirds from the base, as in breviscutum and other allied species.

$H a b$. Swan River, Western Australia.

Easily distinguished by the strong carins on the mesonotum.

XXI.-A reviset Classifteation of the Otomyina, with Descriptions of new Genera and Species. By Ordfield 'Tinomas.

(Published by permission of the Trustees of the British Museum.)

The very striking crauial and dental characters found among the different species of what has hitherto been considered the single genus Otomys, have long seemed to indicate that some subdivision of the geuns would be advisable. 